\title{
THE IMPACT OF THE COVID-19 PANDEMIC ON AKAN DYING, DEATH AND MOURNING RITES
}

\section{Isaac Boaheng}

University of Free State, South Africa, Religion Dept.

\section{Cite this article:}

Isaac Boaheng (2021), The Impact of the Covid-19 Pandemic on Akan Dying, Death and Mourning Rites African Journal of Culture, History, Religion and Traditions 4(1), 15-28. DOI: 10.52589/AJCHRT/S1M4JBR 6.

\author{
Manuscript History \\ Received: 12 Feb 2021 \\ Accepted: 14 March 2021 \\ Published: 27 April 2021 \\ Copyright $(\subset) 2020$ The \\ Author(s). This is an Open \\ Access article distributed \\ under the terms of Creative \\ Commons Attribution- \\ NonCommercial- \\ NoDerivatives 4.0 \\ International (CC BY-NC-ND \\ 4.0 ), which permits anyone to \\ share, use, reproduce and \\ redistribute in any medium, \\ provided the original author \\ and source are credited.
}

ABSTRACT: This study examines how the COVID-19 pandemic has affected Akan traditional rites related to dying, death and mourning. The study used a qualitative research approach (based on both primary and secondary sources) to examine Akan dying, death and mourning rites and selected critical issues arising due to the COVID-19 pandemic. Primary data were obtained from semi-structured interviews and participant observation whiles secondary data were obtained from books, journal articles and others. The study found that though COVID-19 health protocols have changed many Akan traditional rites related to dying, death and mourning, the Akan people still maintain their traditional beliefs about dying, death and mourning. Therefore, there is a high probability that changes that have taken place will be discarded as soon as the pandemic is over.

KEYWORDS: Akan; COVID-19; funeral; death; protocols; social distancing 


\section{INTRODUCTION}

The history of COVID-19 (Coronavirus disease 2019, (caused by the novel coronavirus, SARS-CoV-2) can be traced to Chinese city of Wuhan where, in December 2019, the first cases of the virus were recorded. From Wuhan, the disease spread to other parts of China and to other countries. On March 11th, 2020, the World Health Organization (WHO) declared the COVID19 outbreak as a global pandemic. Ghana recorded the first two cases of COVID-19 on 12th March 2020 (BBC online article 2020). A week later, President Nana Addo Dankwa AkuffoAddo announced a ban on all gatherings (including conferences, funerals, festivals, church services, political gatherings, Islamic worship and others) for the next one month to check the spread of the virus. A three-week lockdown was later announced for the Greater Accra and Greater Kumasi metropolises to check human movements and hence check the spread of the pandemic in those areas.

The virus spread primarily through nose or mouth droplets released via coughing, sneezing, or talking. Nose or mouth droplets from an infested person may drop on a surface and then spreads to another person who touches that surface with the hand and then touches the eyes or nose with the contaminated hand. Based on scientific data available on the mode of spread of the virus, Ghana's Health Ministry came up with a number health protocols which include the mandatory wearing of face mask, the observance of social distancing, thorough and regular washing of hands with soap under running water, the use of alcohol-based hand sanitizers, wearing of nose mask, engaging in regular physical exercise, eating healthy food, staying at home as much as possible, avoiding handshake, and having adequate sleep. Various platforms were used to educate the populace about the virus and how to stop its spread. Later, the government eased some of the COVID-19-induced restrictions in phases. As Ghana's second wave of the pandemic tends to be more serious the first, the government has again announced closure of all borders and has placed restrictions on funeral celebrations, beaches, restaurants and others. Various health protocols are enforced; yet, Ghana's COVID-19 toll keeps rising with a total of 416 deaths (as of 31st January, 2020, when this paper was being prepared).

Like, HIV and AIDs, the COVID-19 pandemic "signals a crisis facing the society, the family, the nation and the world" (Pobee 2006:2). The impact of the pandemic on human lives (including social, economic, religious, political and cultural dimensions) is enormous. The health protocols associated with the pandemic has changed the traditional lives of all societies. In Ghana, for instance, where communal life is preferred to individualistic life, social distancing and lockdowns are a major challenge to people. Traditional ceremonies such as marriages, festivals, funerals, community gatherings, religious gathers, among others, have all been affected by the pandemic. While the effect of the pandemic on every traditional rite is worth studying, the present research focuses on changes in Akan dying, death and mourning rites and selected critical issues arising out of the observance of health protocols associated with the pandemic. The choice of Akan is informed by the dominance of this ethnic group in Ghana and the complexity and elaborate nature of their dying, death and mourning rites. The 2010 population and housing census revealed that, the Akan constitute $47.3 \%$ of Ghana's population (Ghana Statistical Service 2012). 


\section{METHODOLOGY OF RESEARCH}

The study used a qualitative research approach based on both primary and secondary sources of data to examine some of the changes in Akan dying, death and mourning rites and selected critical issues arising out of the observance of health protocols associated with the COVID-19 pandemic. The choice of the qualitative approach was informed by the researcher's quest to have a deeper understanding of the phenomenon under investigation. Semi-structured interviews and participant observation were used to obtain data for the research. Ten (10) expert informants who have knowledge about Akan funeral rites and have witnessed several funeral celebrations in both pre-COVID-19 and COVID-19 periods were purposively selected and interviewed. Through the use of ethnographic technique, the researcher also attended different funerals at different times during the COVID-19 period to have first-hand information on the subject matter. Face-to-face interview was conducted for seven interviewees. Three people could not be reached physically and so telephonic interviews were conducted for them. Information gathered through observation, participation, interviews and literature sources (obtained from books, theses, journal articles and others) were put together to provide a useful resource exploring continuities and changes in funeral rites in the Akan people of Ghana.

\section{The concept of death in Akan traditional context}

The Akan community is one of the principal tribes in West Africa (inhabiting Ghana, Cote D'Ivoire, some other parts of West Africa) that speak the Twi language. They comprise the Adansi, Akwamu, Ashanti, Asen, Akyem, Akuapem, Awowin, Ahanta, Nzema, Bono, Fante, Sefwi, Kwahu, and Twifo. According to Kyeremanteng (2010:26) the name Akan is believed to have derived from Akane or Akana (meaning "first") which was corrupted by early Europeans missionaries to the Gold Coast (now Ghana). Ankrah (2018:59) opines that the Akan moved from the Sahel to coastal West Africa to form the Bonoman kingdom around the 12th century which had Bono Manso as its capital. The language of the Akan people is traced to an ancient chief of Takyiman, Nana Twi, whose language became known as the Twi language. The Akan have many common political, social, religious, and cultural institutions with local variations.

According to Sarpong (1974:71), the crucial turning points in the life of the Akan include: "(1) the time a person enters the world through birth, (2) when he comes of age, and enters the world of adults, (3) when, through death, he departs from this world and enters the world of his forebears." The cycle of life may also be compared to the four stages the sun: "rising (birth, beginning, or re-growth), ascendancy (maturity and responsibility), setting (death and transformation), and midnight (existence in the other world and eventual rebirth)" (cf. Holloway 2005:166). In Akan tradition, each of these three stages is signified by rituals and ceremonies, referred to as "rites of passages."

The Akan word for person or human being is onipa (nipa or nyimpa). Most Akan subscribe to a tripartite composition of onipa (Appiah 2004:28). The first part is the honam/nipadua which comprises basically of the mother's mogya (blood) and probably serves as the for which "there is a closer physiological bond with the mother than with the father" (Radcliffe-Brown et. al 1975:264). The second part is the sunsum (that is, an individual spirit) which comes from one's father at conception, serves as the bearer one's personality, character, suppositions and behavioral or psychological attributes and perishes when a person dies. The third entity, the 
Jkra (the soul) comes from God as a life-giving principle and the bearer of a person's nkrabea (human destiny), and survives after death (Radcliffe-Brown et. al 1975:266).

Death occurs when a person's soul leaves the body. The Akan will therefore say "wahwere ne kra", "he/she has lost his/her soul" or "ne kra afiri ne mu", "his/her soul has departed from his body" to mean someone is dead. Since the skra survives in a disembodied state (as noted above), it is believed that the dead continues to live. This means in Akan thought, death affects the physical body but not the immaterial $\mathrm{skra}$. Death that happens naturally at a ripped age (at least 70 years) after a person has lived a decent life is referred to as owu pa ("good death") while death that occurs through unnatural means like accidents, suicide and others is regarded as and at Jfo wиo or owu bone ("bad death") (Seale and Van der Geest 2004:885).

Death is inevitable according to Akan worldview and this is expressed in the Akan saying "everyone will climb the ladder of death" or "death's cutlass does not weed only one individual" (Adu-Gyamfi et al. 2020:45). Since all persons will eventually die, a person is considered as a sojourner on earth who will return to his original home after fulfilling his/her preordained task (Adu-Gyamfi 2010:11). The Akan saying Baabi a obi awuo no, obi nna ("no one sleeps where there is death") underlines the notion that death is a public concern. In addition, the Akan consider death as a wicked destroyer, a killer, a curse which results in physical separation and a great loss to both the immediate relative and the society as a whole. The Akan notion that death is an enemy to humanity is expressed in the saying, "When death wants you and you call him father, it will take you; if you call him mother, it will take you" (Opoku 1978:134). Though death is considered as a natural phenomenon, it is also believed that supernatural forces (like magic, witchcraft, and sorcery) can cause pre-mature death.

Furthermore, Akan primal worldview considers death as a journey to the land of the ghosts (Asamando/Asamanadze) or a transition from this present earthly life to another life in the spiritual realm. It is only the body which dies; the soul ( $\mathrm{kra}$ ) being immortal, lives eternally in Asamando. Therefore, death does not cut one's connection with the family; it rather extends Akan family relationships to infinity for which reason they perform various rituals to maintain an unbroken relationship between the living and the dead. Consequently, the Akan family is made up of the living, the dead, and even the unborn. The Akan describe death as: returning home, going away, going to the village, sleeping on the left side, turning the eyes to the wall, sleeping, taking one way, saying good-bye, shutting the eye, joining the forefathers and becoming God's property.

On the journey to Asamando, one climbs steep hills and crosses rivers just as many physical journeys are undertaken. The journey requires some necessities (like food and water) and means of transportation (such as money) to ensure a peaceful and successful entrance into Asamando. A ghost who fails to reach the ultimate destination (Asamando) successfully becomes a wandering and aggressive ghost (saman twentwen) who torments the living, especially members of deceased family who refused to facilitate its movement into the world of the ancestors. While a ghost which fails to reach Asamando becomes a form of problem for the family, the one who peacefully and successfully enters Asamando becomes an ancestor and a source of blessing to the family.

Ancestors (Akan: Nananom nsamanfos) are the souls of dead heroes and heroines who, after death, have acquired super-human powers and are able to affect the lives of the living (Quarcoopome 1987:128). One has to die a natural death at a "ripe age" after leading a decent 
life and having offspring together with a proper burial and elaborate funeral rites before qualifying as an ancestor (Quarcoopome 1987:128). The Akan concept of ancestors is informed by the belief that the soul continues to live after death and can fellowship and communicate with the living (Quarcoopome 1987:128). During funerals the living send message to their ancestors through the dead and the ancestors may also give a message to the living through a family member (in what is referred to as nsamanksm). The Akan pour libation to their ancestors and offer sacrifices to them to seek blessings such as fertility, long life, prosperity, among others. The ancestors therefore determine the fate of their descendants (asefoj) on earth. Quarcoopome (1987:130) sums up the important role of ancestors in the life of the living as follows:

They are the guardians of family affairs, property, traditions, ethics and activities. Offence in these matters is ultimately against the forefathers, the divinities and ultimately God, the source and upholder of the social and moral orders. In this regard, the ancestors act as invisible police force of the families and communities. They are the unseen presidents at family meetings. In other words, the ancestors are the spiritual superintendents of earthly families of which they remain members and not mortal anymore.

The Akan also believe that life after death is similar to life on earth. Consequently, the dead is to be given some means of beginning a new life at Asamando. It is against this background that the Akan bury their dead with items such as sponge, towel, pomade, cooking utensils, money (saman sika) and other necessities for life. It is also believed that people live in the spirit world undertaking the same occupation they undertook in the land of the living (Quacoopome 1987, 127). Therefore, Akan bury their kings with other people to serve as servants in the spirit world. Some wives may also volunteer to be killed or are forcefully killed to accompany their dead husband (Quacoopome 1987:127).

The Akan believe in reincarnation of the soul (Quarcoopome 1987:126; see also Adu-Gyamfi et al. 2020:45). The Akan name Ababio ("she/he has come back" like the Yoruba name Babatunde) is given to a child who is believed to be an ancestor who has returned to the family. The reason for such return may be that the ancestor has some uncompleted work in his/her first earthly life which he/she needs to return to complete (Quarcoopome 1987:126). The Akan therefore believe that birth on earth is death in the spirit world and death on earth is birth in the spirit world (Ofori 2014:55). The believe in reincarnation is expressed by the Akan sayings like "It is those who go to the land of the dead who return to be born," "If people don't go, others don't come" or "Nobody gives birth to another person's ancestor" (Ofori 2014:55).

\section{Akan Funeral Rites}

From the foregoing discourse, it is apparent that the living has the responsibility to give the dead befitting burial rites and organize well-celebrated funerals for them to maintain good relationship with the spirits of their death relatives. In this light, the living relatives of the dead therefore always ensure that proper funeral rites are performed with accompanying gifts to enable the dead reach Asamando. Akorno (cited Mensah online article 2013:np) thus asserts that "People believe that without a befitting burial, the dead cannot rest in peace and may even come back to punish the family for failing to bid it farewell in a proper manner." What Akorno calls "befitting funeral rites" include various traditional and religious rites and ceremonies meant to facilitate the migration of the deceased to the ancestors in the invisible world. 
In Akan, ayie or ayiys (funeral rites) is performed for those who die naturally. Funerals are social gatherings at which family members, children of the bereaved and friends pay their last respect to the dead. There are two kinds of ayiys, namely, dsteyie which comprises all the rites that take place from the time that a body is laid in state to the times that it is buried and ayipa which refers to the funeral proper which takes place after the burial. In the olden days when there were no morgues, the dsteyie was usually performed within three days after death. Those who die unnaturally, at Jfo wuo (for example dying through suicide or accident), do not usually have any proper funeral rites performed for them. Moreover, funerals are not organized for babies and first-born children. Anane-Agyei (2015:156) relates this practice to the belief is that organizing a funeral for first born-children may result in the death of other children of the parents.

Akan funerals are occasions to honor dead relatives; therefore, "any person whose funeral was not celebrated lingers on the path which leads to the land of the dead" (Adu-Gyamfi et al. 2020:46). Funeral celebrations are very common in Akan communities. In almost all Akan society, not less than two funerals are celebrated a week. When a person dies it is the abusupanyin (or abusupanyini, family head) who leads the performance of traditional rituals (including burial and funeral celebration). During the period of mourning the family of the deceased person fast (Akan: тmиаda die), not total abstinence from all food but abstinence from their staple food until the funeral is over (Anane-Agyei 2015:156). Mmuada die serves as a sign of their grief and respect for the dead. Elders chew kola nut and women sing dirges to symbolize their grief, "praise the deceased and philosophize on life and death generally" (Opoku 1978:135).

The success of Akan funeral depends on the number of dignitaries in attendance and this is expressed by saying "ayie no aba" ("the funeral has been well-attended"). The number of attendees (which usually depends on the deceased person's social status, inter-personal relationship with members of the society, number of children who are married, level of publicity of funeral rites and so on) also shows the level of affection people have for the deceased and their family. The family consider the funeral as a way of glorifying the dead and so they may say "Yerehye no animuonyam" (We are glorifying the dead) (Adu-Gyamfi et al. 2020:46).

Traditionally, the Akan organize one week celebration for the deceased and at this celebration, the arrangement for final funeral rites were announced. Rituals such as pouring of libation, shaving and others were associated with the celebration. On the fortieth day the family met to inspect the property of the decease and to perform certain rites associated with the transfer of the ghost of the decease into the world of the ancestors. It is usually after this that the final funeral rites are observed in one or two days (depending on what prevails in one's society). The observance of the final funeral rites takes place throughout the day (from 6.00 am to 6.00 $\mathrm{pm}$ ). Usually, funerals take place at the weekend or on Thursdays (when many people do not engage in farming activities). The Akan community is predominantly a farming community and Thursdays are set aside as holidays; no one goes to farm because it is a sacred day for the land (referred to as Asaase $\mathrm{Yaa}^{1}$ because of the belief that the land is a Thursday born). Funerals organized on Thursdays do not normally continue the following day (Friday). However, those organized on Saturdays continue on Sunday (after church service) or from 6.00am to $6.00 \mathrm{pm}$

${ }^{1}$ Asaase means land and Yaa is the Akan name for a female Thursday born. 
depending on whether or not the deceased person was a member of a denomination. As part of the Akan hospitality, sympathizers are given, water, drinks and food at funerals. In additions, those from far places are given accommodation. It is part of Akan custom to greet and/or welcome strangers through handshake. Therefore, as part of funeral rites, the deceased family will usually sit under canopies and shake hands with sympathizers who come to mourn with them.Soyoo I (cited in Adamu online article 2020) therefore notes that "Shaking hands with the family of the deceased is a deep-rooted tradition in many Ghanaian tribes that has taken place for hundreds of years and has become a mandatory part of ceremonies to show respect for the dead... A significant part of funerals is bringing families together to embrace through handshakes, hugs and to mourn in close proximity of one another."

The family then gathers on Monday morning (or the day following the final funeral rites) to have a retrospective reflection on the funeral and to render accounts of the funeral to the family members. This is followed by thanksgiving errands undertaken by a group of family members who move from house to house to shake hands with sympathizers as a sign of gratitude. This is done in addition to thanksgiving announced on radio and television. All these aspects of the funeral are very necessary according to Akan traditional life and thought.

\section{RESULTS AND DISCUSSIONS}

In this section the study discusses the results from interviews and personal observation in the light of existing literature on Akan funerals.

\section{Dying in Isolation}

The Akan do not die in isolation. The last moments before death are considered to be very significant for both the dying persons as well as their families. The Akan usually wish to die with family members and other close acquaintances surrounding them and providing them encouragement and comfort. This enables the person about to die to give some last instruction or advise, confess $\sin (\mathrm{s})$ and seek forgiveness and reconciliation. Therefore, every critically-ill person is always accompanied by a family member or friend who takes care of his/her needs. Another reason why a person about to dies need relatives to be around is the need to perform a certain Akan ritual, outlined below. When a person is about to dies, the elderly female relative, the family head or any one taking care of the person, offers them water to drink (Ofori 2014:32). The following words accompany this ritual: "Receive this water and drink, and do not permit any evil to come whence you are setting out, and permit all women of this household to bear children" (Ofori 2014:32). As noted earlier, the Akan believe that the journey from the world of the living to the land of the dead involves the ascending and descending of a high mountain. The water is therefore expected to revive the spirit of the one who is about to die to climb this mountain and eventually cross to the other world (Ofori 2014:32; see also Adu-Gyamfi et al. 2020:46). Therefore, to leave someone to die in isolation is to deprive the person from obtaining extra energy from the water that people usually drink just before their death. Most people die immediately after drinking water. After the death, a close relative of the deceased or their children give the corpse a ritual bath in preparation for public display. Alcohol, salt solution, lime and camphor balls are forced down the throat of the corpse for preservation purposes.

The COVID-19 pandemic has however brought a situation where people have to die in isolation because of the contagious nature of their diseases. The researcher has observed that most Akan 
go through a lot of struggle just before they die because of the lack of water as source of extra energy for the transition to the land of the dead. For COVID-19 patients, family members are not allowed to get close to their dying relatives because such a practice would increase the rate of infectivity in the hospital and the high risk of spreading of the virus. People prevented from taking care of their terminally ill relatives because of COVID-19 restrictions, end up experiencing an additional level of complexity to the grief of their loved ones. The trauma people pass through after letting their relatives die without performing the religious-cultural rituals at the time of death is great.

Should a person be diagnosed with COVID-19, their immediate family is quarantined. If the person dies immediately, then their family members are not able to participate in the funeral because of being in quarantine. Since burial for those who die of COVID-19 are buried immediately, they often buried in the absence of the close family members, as they remain in quarantine. Here, one agrees with Wasia and Jahangir (2020:15) that "the presentation of the dead persons' face to the bereaved for the last time is considered to be highly significant. Coming across the face of the deceased individual is thought to be useful in recognizing the reality of loss since it clarifies any doubt about the death." Obviously, though the pandemic has not in anyway changed the Akan belief about the journey associated with death, it has changed the way people undertake the journey. People still believe that they can be punished if he/she refuses to treat the sick well (Mercy Osei, interview 2021). In the post-COVID Akan society, the Akan practice of attending to their relatives who are about to die will definitely continue.

Dying in isolation, in the mind of the Akan, is unacceptable because it is believed that the number of people surrounding the person about to die (among other factors) informs the number of dead spirits who will welcome the dead into the land of the dead. Therefore, as people die without anyone around them, they will not be welcome well in the land of the dead, their ghosts may hover and harm their family members on earth. An interviewee disclosed "Few hours before his death, my daughter made a video call and I was delighted to see her. I was glad to see her again after some weeks. This, however, did not offer me the opportunity to hold hands, take care of her face-to-face [as custom demands] and experience deep connections. I don't know if her ghost will pardon me" (Kwasi Gyau interview 2021). Another interviewee said "I pray I don't die in this period. If you die now you will be buried like a witch/wizard or as someone who has no relative" (Mary Ampomah interview 2020). The point is that even though Akan organized elaborate funerals, such arrangement is not made for deceased witches and wizards. For most people, the fact that they were denied access to their sick relatives makes it difficult to accept the loss.

\section{Mourning in Isolation}

Weeping for the dead is a significant part in Akan funeral celebration. Weeping and wailing is mostly done by women right from the time of death of relative until the commemorative ceremonies. As a way of expressing grief, weeping and wailing over the dead person provide comfort, solace, hope, and even inspiration following the death of a loved one. Mourning in isolation without the dead body denies people their traditional right to weep over the corpse of their loved ones. Such situation makes people take a longer time to relieve themselves of pain resulting from the passing away of their loved ones. 
An interviewee lamented

When my father died early January 2020, I was expecting at least 1500 to attend the funeral and so I needed much time to make enough preparations. Unfortunately for me the president announced some restrictions and limited the number of people who can attend burial to twenty-five people. I had no choice than to make painful phone calls inviting only twenty-five people. The family had to cut all the in-laws and the grandchildren. None were able to attend. It was very painful. The large funeral home we had booked to hold the funeral was moved into a small, private chapel within the same venue (Adwoa Martha interview 2020)

"Psychologically no one wants death to occur now because funerals are time of family gathering, to meet other members to settle other family issues" (Paul Asante Bonah 2021 interview). Another implication of private mourning is that "families will be unable to connect. This is something that has never happened in generations and it is definitely going to have a social impact" (Adamu online article 2020).

\section{Private Burial}

In the Akan community, burial is not a private activity. Burial is a public ceremony involving the entire members of families, friends and well-wishers. Presently, the government of Ghana banned burials and later allowed private burials involving not more than 25 people. With this restriction, deceased people do not get the opportunity to lay their dead in stay, keep wake and enjoy the company of sympathizers. Funeral practices such as wake-keeping and laying in state have almost faded off (Isaac Nyanful, interview 2021). Corpses are buried without being laid in state. The Akan usually live in compound houses which usually have a space used as dining hall for the family and at the same time as a place where dead family members are laid in state for public viewing. The space is called pato mu. One is usually laid in state in the pato mu of his/her father's house. That rite connects each person to the father and indicates that a person really has a responsible father. To be deprived of this rite (laying on state) is therefore not culturally proper within the Akan worldview. A man narrated her experience on this: When the president announced the restrictions on funeral rites, my daughter was in the morgue. Initially, we wanted to wait till the restrictions were over but later, we decided to bury her. It was very painful to have my daughter sent from the morgue to the cemetery without even the close relatives having the opportunity to say goodbye to her" (Alex Yeboah, interview 2021). Corpse are now bathed in the mortuary, dressed there and placed in the casket. The body is then conveyed from the mortuary straight to the cemetery to be buried without giving opportunity even to the immediate family to say "good-bye" to their loved one. The restriction put a lot of pressures on the weak mortuary services in Ghana, and eventually the government asked people to bury their dead as soon as practicable. This was to be do in a way that would ensure the rights of the dead to a befitting burial.

\section{Socio-economic dimension}

Akan elaborate funeral celebrations involved huge expenditure. Publicity, laying in state, food and drinks, accommodation, are among the factors that contribute to the high spending on Akan funerals. The Akan say with pride "I spent so much on my mother's, father's funeral." The reason is that when a funeral is well organized and patronized, the whole family gain accolades. Therefore, the Akan will gather all resources to have an elaborate funeral for their deceased 
relatives. Pauline Bax righty asserts The Akan spare "no [funeral] expense because [they] care more about the dead than the living (Bax 2013 online article). This observation agrees well with the Akan saying abusua do funu ("Relatives love corpse [more than the living person]"). There are many people who suffer in life without anyone to cater for them. Yet, when they die, they have people organize flamboyant funerals for them.

One of the reasons why funeral celebrations are expensive is infrastructural development. Usually, when a person dies the family members make sure they put their family house in order by renovation through plastering, painting, rebuilding and other means. There are some wealth people who even tar the road leading to their village because of an upcoming funeral. Funerals draw people from many places and the wealthy person may be embarrassed to have his/her friend journey on bad roads that lead to the village where the funeral is taking place. One interview stated his experience as follows:

When my father died, I knew that my business partners would come to celebrate with me. The government had given the road to my village to a contractor who had not yet started the construction. I took it upon myself to construct about 5 kilometers of the road to save myself from the embarrassment I would go through if my friends come to realize that our roads are poor (Mercy Osei, interview 2020).

Another factor that increased expenditure is publicity. In the Akan community, funeral publicity is very important. There is the saying that ayie ye nkJgya nkJgya ("Funeral celebration is "you come to mine and I come to yours" or "I will come to help you celebrate the funeral of a deceased person, expecting that you will reciprocate this kind gesture when required"). There is another saying obi ayie ase na yey $\varepsilon$ ye ho ayie ("It is at someone else' funeral that another person celebrates his/her own funeral). This saying has two implications. First, as one mourns another person, they are mourning for their own death which is yet to come. In other words, another person's funeral is a reminder that one day the mourner will also die and have their own funeral celebrated. The second implication is that the number of people to attend a person's funeral depends on the person's involvement in other people's funeral. The foregoing discourse underscores the need for publicity. When a person dies it is the living relative who can inform other about the death and funeral arrangements so that people can reciprocate the deceased person's funeral attendance. Messengers are sent to inform the chief of the village and other key people. In addition, funeral announcements are made through the electronic like radio, television (both state owned and private television stations), Facebook, WhatsApp and others. The print media is also used to publicize funerals. Funeral cars are printed and distributed, banners, posters, handbills, T-shirts are also involved in publicizing funerals, pictures of deceased persons are replicated in the classified pages of local newspapers announce their funeral arrangements large, colorful and expensive billboards are erected at vantage points to publicize funeral arrangements. Funeral brochures are printed for burial services and funeral celebrations. These brochures, usually flooded with full-colour pictures, are expensive to print.

Caskets also play key role in Akan funerals. The era of simple casket or adakateaa (an unpolished coffin made of Wawa, Odum or Mahogany) has given way to modern coffins made of plastics, metal, fiberboard and fiberglass and flamboyantly decorated with broken mirrors, white linen, polyester, flowers, shiny silver, bronze/gold plates, among others. Caskets are now made to reflect the occupation of the deceased. Therefore, a cocoa-shaped casket is made for a cocoa famer, a fish-shaped casket for a fisherman, a microphone-shaped for a musician, a 
Bible-shaped casket for a pastor and so on. The customized caskets Ghana which highlights the legacy and reputation of the deceased and other modern caskets which are imported from other countries (usually from United Kingdom or the United States of America) are very expensive. Some of these caskets may cost as much as $\$ 10,000$ (online article).

Funeral cloth and souvenirs also contribute to funeral expenses. The common Akan cloth for funeral is black (brisie) or red cloth (kobene). In addition, various families have their own family cloth for funerals. More so, there are special (customized) mourning clothes for each funeral. People end up spending so much on mourning cloths. Modern Akan funerals also involve the use of customized handkerchiefs, face towels, wristbands, cups and bowls, writing pads, pencils, pens, key holders made in the name of the deceased. Other factors that increase funeral expenses include canopies, chairs, food, drinks, and so on. The above discussions make it clear that traditional Akan funerals are very expensive.

In the COVID-19 period it is difficult to obtain funds for funerals. The negative effect of the COVID-19 on economic activities (such as the catering industries, textile industry, the tailors, dressmakers, the choral groups, event planners, and so on) makes it difficult to have enough funds to prefinance expensive funerals. An interviewee had this to share:

During the first wave of the COVID-19, my grandmother died and was to be buried the following week. My uncle was had usually prefinance funerals of family members declined to prefinance this one because he knew the private nature of funerals at the time could not make him get back his money. The family was compelled to sell the deceased person's cocoa farm to organize the burial (Beatrice Asuamah, interview 2021).

Another person also revealed that "the two funerals that have been organized in her family have been poorly organized because of lack of fund to prefinance them" (Mercy Osei, interview 2021). The person indicated that it has even become difficult to get a loan to prefinance funerals because most families who have borrowed money for funerals have not been able to pay back (Mercy Osei, interview 2021).

After spending huge sums of money to organize funeral, sympathizers are expected to come in their numbers with huge donations to help the deceased family to cater for the cost of the funeral. One person who was part of the funeral committed of her siter's funeral had this to say: "At the end of my sister's funeral, the donations we had from sympathizers exceeded the cost of the funeral. The excess was used to established a family funeral fund" (Mercy Osei, interview 2021). The person further asserted that "families usually spend mush on organizing funerals with the hope of getting enough donations to pay for the funeral expenses" (Mercy Osei, interview 2021). Therefore, generally speaking, the level of extravagance is informed by the expected income. In the COVID-19 era, "funeral expenses have reduced with regards to food, drinks, accommodation, publicity, laying-in-state, entertainment and others" (Isaac Nyanful, interview 2021). At the same time "the number of mourners has reduced drastically due to the disease. This has reduced income at funerals" (Ampabeng Kyeremeh Hayford, interview 2021).

Handshaking at Akan funerals is now replaced by various kinds of hand waves at funerals. Sitting arrangement has also been affected due to the observance of social distancing. People no more enjoy funeral celebrations as they used to. An interviewee therefore says, "The 
COVID-19 pandemic has changed how we socialize/ it has affected socialization. Socialization sometimes makes one finds partners, friends, concubines and so on, but for the fear of the virus people no longer socialize at the funeral grounds hence denied their chances of making new friends" (Gyasi Boateng interview 2021).

Handwashing and the use of hand sanitizers have now become part of Akan funerals observances. Before, the COVID-19 however, the Akan had a handwashing ritual as part of their funeral celebration, but for a different purpose. Usually, large crowds accompany the casket to the cemetery amid shooting or guns, singing and dancing. The shoot of guns is believed to inform the spirits of the dead that their brother/sister is coming to join them so they should come and welcome him/her home. It is believed that the crowds of spirits who come to welcome the dead into their company is informed by the number of people who accompany the casket to the cemetery. Therefore, many people would like to be part of the journey from the family house to cemetery. It is also important for the Akan to know where their relatives were buried. Upon arrival from the cemetery pots of water with a special leaf (sume) are placed at the entrance for everyone who accompanied the deceased to the cemetery to wash their hands. The belief is that the concoction will ward off any evil spirit that might have accompanied them back home. In the view of the researcher this practice also has the health benefit of removing any physical dirt that might have contaminate the body. This special cleansing exercise is no more possible because it does not take place under running water, which is required for washing in the COVID-19 era. The special leave that effects the cleansing cannot be used under running water. Physical cleansing is however achieved by hand washing with soap under running water or through the use of hand sanitizers. A mourner said, "I know that the hand sanitizer can kill germs. It can however not deal with evil forces that might have accompanied me from the cemetery. Washing hands with soap under running targets my physical body, the spiritual dimensions is left unattended to" (Mary Ampomah, interview 2021).

Due to the COVID-19 people now spend little time at funerals. Instead of two days, one day or even few hours in the day are used for the entire celebration. Instead of converging at the family house to render accounts of funerals, most families now give the mandate to few representatives (about five to ten people) to carry out this assignment on behalf of the entire family. Someone had this to say "The time for family reunion to discuss matters relating to family is not well functioning because for the fear of the virus, most of the family members will not attend the funeral" (Gyasi Boateng, interview 2021). Family members no more move from house to house to thank sympathizers. Many people refuse to attend funerals in person because of health protocols and the risk involved. Organizers of funerals have therefore resorted to virtual funeral to ensure the participation of people from any location (Adamu online article 2020). Nyanful (interview, 2021) said that "People spend less time at the funeral grounds which makes the grounds almost empty as if the funeral was not well attended." At the same time "The issue of social distancing due to the covid19 has forced the organizers of the funerals to look for spacious environment, more canopies, many chairs. This will increase their cost." Gyasi Boateng, interview 2021). In addition, face masks conceal the anguish on the faces of mourners. 


\section{CONCLUSION}

The study has shown that the pandemic has affected many aspects of Akan death and mourning rituals. From the study it can be concluded that the Akan traditional way of funeral and its associated rituals has the tendency of increasing the spread of the COVID-19 virus. The traditional goodbye rituals of bathing corpse, gathering at the family house in large numbers, exchange of greetings and offering of commiserations (usually involving handshaking and hugging), handling of food packs and water in their distribution and receiving during funeral receptions, eating and drinking during receptions (which necessitates the removal of protective face/nose mask), handling of funeral donations (usually money) from sympathizers, among others put people at risk.

At the same time, the observance of the health protocols and its associated changes in Akan funeral rites is a big blow to Akan traditional beliefs and practices related to death and funerals. The research opines that the Akan though these changes may affect the relationship between the dead and the living (from Akan traditional perspective), there is no option than to adhere to the "new normal" and save lives. Whether Akan ancestors will pardon the living for failing to have a "befitting" farewell for them because of the pandemic is another question. In the opinion of the researcher, ancestors are "reasonable" beings who would not punish the living for failing to do what they have no control over. It may however be necessary (based on Akan primal religious thought) to make sacrifices to the ancestors to make up for what could not be done by way of funeral and burial rites. In view of this the paper encourages all traditional rulers, opinion leaders and community elders to encourage their people to adhere to the new way of organizing funerals and burials.

\section{REFERENCES}

Adamu, Zaina. 2020. Ghana's lavish funerals can last up to seven days. Now, a centuries-old tradition has gone online [Retreived on 12/12/2020 from https://edition.cnn.com/2020/04/08/world/africa/ghana-burial-traditions-intl/index.html]

Adu-Gyamfi, Paul. 2010. Observable Artistic Changes in the Funerals of Adanse Traditional Adu-Gyamfi, Samuel et. al. 2020. "Funerals Among the Akan People: Some Perspectives On Anane-Agyei, Nana Agyei-Kodie. 2015. Ghana's Brong-Ahafo Region: The Story of an African Society in the Heart of the World. Accra: Abibrem Communications.

Ankrah GK 2018. "The Effect of Lexical Borrowing in Techiman: A Case Study in the Brong-Ahafo Region of Ghana." In European Journal of Literature, Language and Linguistics Studies. Vol. 2(4):53-74.

Appiah, K. A. 2004. "Akan and Euro-American Concepts of the Person" in Lee M. Brown (ed), African Philosophy: New and Traditional Perspectives. Oxford: Oxford University Press.

Area. Master of Arts in African Art and Culture: Kwame Nkrumah University of Science and Technology.

Asante.” Revista De Etnologie Și Culturologie. XXVII: 44-53. DOI: doi.org/10.5281/zenodo.3956748

Bax, Pauline. 2013. "In Ghana, Funerals Have Become Big Business" [Retreived on 12/12/2020 from https://www.bloomberg.com/news/articles/2013-08-22/in-ghanafunerals-have-become-big-business]. 
BBC, "Coronavirus symptoms: Ghana don record first cases of Covid-19 outbreak, patients enter Ghana one week before symptoms start dey show" (13 March 2020) [Retrieved, on 4th December, 2020, from https://www.bbc.com/pidgin/tori-51867414]

Ghana Statistical Service 2012. Population and Housing Census 2010. Accra: Sankofa Press limited.

Hamid, Wasia and Jahangir, Mohmad Saleem. 2020. "Dying, Death and Mourning amid COVID-19 Pandemic in Kashmir: A Qualitative Study" in OMEGA-Journal of Death and Dying, 1-26.

Holloway, Joseph E. 2005. Africanisms in American Culture second edition. Bloomington: Indiana University Press.

Kyeremanteng NK 2010. The Akan of Ghana: Their Customs, History and Institutions. Kumasi: Sebewie De Ventures.

Mensah, Dorcas Efe. 2013. "When death takes away everything: Funerals leave families broke" [Retrieved on 1/1/2021 from:http://training.dw.de/ausbildung/blogs/mm13accra/?p=1141]

Ofori, Samuel. 2014. Christianity and African Culture-The Gospel in Asante Funeral Rites. Np: Pentecost Press Ltd.

Pobee, John S. 2006. "HIV/AIDS in Africa: A Biblical Response" Paper presented at WAATI Conference. Kumasi, Ghana.

Quarcoopome, T. O. N. 1987. West African Traditional Religion (Ibadan: African Universities Press.

Radcliffe-Brown, A. R. et. al (eds). 1975. African Systems of Kinship and Marriage. London/New York/Toronto: Oxford University Press.

Sarpong, Peter. 1974. Ghana in Retrospect: Some Aspects of Ghanaian Culture. Tema: Ghana Publishing Corporation.

Seale, C. and van der Geest, S. 2004. "Good and Bad Death: Introduction" in Social Science \& Medicine 59 (5): 883-886. 